\title{
Stability in chromosome number and DNA content in synthetic tetraploids of Lolium multiflorum after two generations of selection
}

\author{
Roselaine Cristina Pereira ${ }^{1}$ Natália de Souza Santos ${ }^{1}$ Fernanda de Oliveira Bustamante $^{1}$ \\ Andrea Mittelmann ${ }^{2}$ Vânia Helena Techio ${ }^{1 *}$
}

'Departamento de Biologia, Universidade Federal de Lavras (UFLA), 37200-000, Lavras, MG, Brasil. E-mail: vhtechio@gmail.com. "Corresponding author. ${ }^{2}$ Embrapa Gado de Leite, Embrapa Clima Temperado, Juiz de Fora, MG, Brasil.

ABSTRACT: Chromosome doubling of Italian ryegrass genotypes (Lolium multiflorum Lam.) adapted to the brazilian edaphoclimatic conditions is an important strategy used by breeders and aims to obtain more vigorous genotypes with better forage quality and disease resistance. The effectiveness of chromosome doubling can be measured by genetic stability and fertility rates of plants over generations. However, a common problem in the polyploidization process is the regeneration of mixoploid plants that have impaired fertility and genetic stability. The objective of this study was to verify if progenies of recently tetraploidized plants remain stable regarding DNA content and chromosome number, over two generations. Progenies of L. multiflorum plants artificially tetraploidized with colchicine treatment were evaluated. Chromosome counting and estimates of the DNA content were used to evaluate the genetic stability. The percentage of tetraploid plants $(4 X)$ increased over generations $(18 \%, 34 \%$ and $91 \%$ in cycle 0,1 and 2, respectively). All progenies identified as tetraploid by flow citometry showed variation in chromosome number (mixoploidy), but produced viable seeds. Results showed that stabilization in chromosome number and DNA content in tetraploidized plant progenies requires time and that the success of this procedure depends on a continuous and accurate screening and selection.

Key words: chromosomal duplication, mixoploidy, Italian ryegrass, plant breeding.

Estabilidade no número cromossômico e no conteúdo de DNA em tetraploides sintéticos de Lolium multiflorum após duas gerações de seleção

RESUMO: A duplicação cromossômica de genótipos de azevém anual (Lolium multiflorum Lam.) adaptados às condições edafoclimáticas brasileira é uma estratégia importante usada pelos melhoristas e visa a obtenção de genótipos mais vigorosos com melhor qualidade de forragem e resistência a doenças. A eficiência da duplicação cromossômica pode ser medida pela estabilidade genética e taxas de fertilidade das plantas ao longo das gerações. No entanto, um dos problemas comumente encontrados no processo de poliploidização é a regeneração de plantas mixoploides que apresentam comprometimento na fertilidade e instabilidade genética. O objetivo deste estudo foi verificar se progênies oriundas de plantas tetraploidizadas recentemente se mantêm estáveis quanto ao conteúdo de DNA e ao número cromossômico, ao longo de duas gerações. Foram avaliadas progênies de plantas de L. multiflorum tetraploidizadas artificialmente com tratamento de colchicina. A estabilidade genética foi avaliada por meio de contagens cromossômicas e estimativa da quantidade de DNA. A porcentagem de plantas tetraploides (4X) aumentou ao longo das gerações (18\%, 34\% e $91 \%$ no ciclo de 0,1 e 2, respectivamente). Todas as progênies identificadas como tetraploides por meio de citometria de fluxo apresentaram variação no número cromossômico (mixoploidia), entretanto, produziram sementes viáveis. Os resultados demonstraram que a estabilização no número cromossômico e no conteúdo de DNA em progênies de plantas tetraploidizadas requer tempo e que o sucesso desse procedimento depende de um contínu e rigoroso monitoramento e seleção.

Palavras-chave: duplicação cromossômica, mixoploidia, azevém, melhoramento genético.

\section{INTRODUCTION}

Poliplodization is an important strategy used in forage breeding programs, because it may increase the expression of agronomic traits of interest, restore fertility of intra- and interspecific hybrids, and, in some cases, permit the exploration of genetic variability in apomictic species by duplicating sexual plants and equaling the ploidy to allow the accomplishment of crossings and obtaining fertile offspring (PEREIRA et al., 2001; NAIR, 2004; BARBOSA et al., 2007; CAMPOS et al., 2009; ISHIGAKI et al., 2009; SIMIONI \& VALLE, 2009; PEREIRA et al., 2014; TIMBÓ et al., 2014).

In Brazil, polyploid genotypes have already been obtained in several forage species and hybrids such as: Brachiaria brizantha, Brachiaria decumbens, Brachiaria ruziziensis and hybrids between $B$. decumbens, B. brizantha and B. ruziziensis (PINHEIRO et al., 2000; SIMIONI \& VALLE 2009; TIMBÓ et al., 2014), triploid hybrids of Pennisetum glaucum x Pennisetum purpureum (BARBOSA et al., 2007; CAMPOS et al., 2009) and Lolium multiflorum (PEREIRA et al., 2014).

The ploidy and chromosome number of synthetic polyploid of Brachiaria, Lolium and Pennisetum were identified by flow cytometry and chromosome counts, and the fertility was verified by pollen grain viability (CAMPOS et al., 2009; TIMBÓ et al., 2014; PEREIRA et al., 2014; PAULA et al., 2014). Polyploid plants were incorporated into breeding programs. 
However, in order to be successfully used in crossings, these plants have to be and remain fertile and stable over generations. In various studies on induced polyploidy, the regeneration of mixoploid plants has been reported as a major problem, since the genetic stability of these partial polyploids is unknown. Another aspect to be considered, and usually neglected, is the delayed effect of colchicine (LUCKETT, 1989), the main polyploidization agent used in grasses, which can lead to chromosomal losses and rearrangements with strong impacts on fertility (LUCKETT, 1989).

All together, these factors can difficult the maintenance and use of these plants in breeding due to genetic and phenotypic instability. Thus, we have to plan a long-term, systematic monitoring of tetraploidized plants and their progenies. This procedure can provide the breeders information about plants that effectively remained polyploid and prevent the use of plants that were not tetraploidizeds in crossings. Thus, this study analyzed the stability of DNA content and chromosome number in progenies of recently tetraploidized plants of L. multiflorum over two generations. These two parameters, used in combination, provide a reliable reference to confirm chromosome duplication, determining if the genetic material has undergone postpolyploidization undesirable changes, which affect genomic/chromosome stability of plants.

\section{MATERIALS AND METHODS}

The access LOL 161 from the Ryegrass Active Germplasm Bank of Embrapa Gado de Leite (Embrapa Dairy Cattle - Brazilian Research Institution, Juiz de Fora, Minas Gerais State, Brazil) was used in this study. To induce chromosome doubling, diploid seedlings $(2 n=2 x=14)$ were immersed for 24 hours in two antimitotic solution concentrations (treatment 1: $0.1 \%$ colchicine with $1 \%$ dimethyl sulfoxide - DMSO; treatment 2: $0.25 \%$ colchicine with $1 \%$ dimethyl sulfoxide - DMSO) as described by PEREIRA et al. (2014). Ploidy of plants was validated by assessing the DNA content by flow cytometry and chromosome counting. Tetraploid plants obtained, called Cycle 0 plants, were grown in a greenhouse and their fertility was checked by pollen and seed production, as described by PEREIRA et al. (2014).

Seeds of Cycle 0 plants were collected and sown to obtain Cycle 1 plants. The progenies of these plants were called Cycle 2 plants. DNA content determination was the parameter used to screen and select ploidy in both cycles.

Flow cytometry was employed to determine the DNA content, according to the protocol of DOLEZEL et al. (1997) modified by PEREIRA et al. (2014). For each sample, 10,000 nuclei were analyzed using a logarithmic scale. Analysis was performed using FACS Calibur cytometer (Becton Dickinson), the histograms were constructed with the Cell Quest software and used WinMDI 2.8 software for ploidy determination.

The chromosome number was determined by evaluating meristematic cells from root tips pretreated with ice water $\left(0^{\circ} \mathrm{C}\right)$ for 24 hours and fixed in Carnoy (ethanol: acetic acid 3: 1). Slides were prepared by squash technique and stained with $3 \%$ Giemsa for 5 minutes. The frequency of tetraploid plants in each generation was calculated.

\section{RESULTS AND DISCUSSION}

In the generations after chromosome duplication induction it was possible to recover tetraploidized plants at different frequencies (Table 1). In cycle 1 , the progenies derived from each plant of the cycle 0 were individualized. Thus, a sample of each e progenies were evaluate and only those with DNA content (about 12pg) consistent with the chromosome duplication were selected.

In cycle 0, among the 192 seedlings exposed to induction of chromosome doubling, 114 plants were obtained, 82 from the treatment with $0.1 \%$ colchicine $+1 \%$ DMSO and 32 from the treatment with $0.25 \%$ colchicine $+1 \%$ DMSO. Of the plants of this cycle, about $18 \%$ had DNA content $(12.05 \mathrm{pg}$ ) and chromosome number consistent with the tetraploid condition $(2 \mathrm{n}=4 \mathrm{x}=28)$ (Table 1). Treatment with $0.25 \%$ colchicine $+1 \%$ DMSO was more efficient, as it resulted in seven tetraploid plants, comprising about $22 \%$, compared to the treatment with $0.1 \%$ colchicine $+1 \%$ DMSO, whose frequency was $17 \%$ (PEREIRA et al., 2014).

The 21 tetraploid plants obtained in cycle 0 showed normal development, flowered and produced seeds. These seeds were sown and produced 164 plants of cycle 1 (81 plants from the treatment with $0.1 \%$ colchicine $+1 \%$ DMSO and 83 from the treatment with $0.25 \%$ colchicine $+1 \%$ DMSO), of which 96 plants were evaluated. In this evaluation, $34 \%$ of the plants showed the tetraploid state (Table 1), indicating that despite of the selection made in cycle 0 , based on DNA content and chromosome number, non-duplicated and 
Table 1 - Number of seedlings treated with colchicine, number of surviving and tetraploid plants in cycle 0 and number of plants obtained, evaluated and tetraploids of cycles 1 and 2 .

\begin{tabular}{|c|c|c|c|}
\hline & Number of treated seedlings & Number of surviving plants ${ }^{1}$ & Number of $4 x$ plants ${ }^{2}$ \\
\hline $0.1 \%$ colchicine $+1 \%$ DMSO & 96 & 82 & 14 \\
\hline $0.25 \%$ colchicine $+1 \%$ DMSO & 96 & 32 & 7 \\
\hline Total & 192 & 114 & 21 \\
\hline \multicolumn{4}{|c|}{ 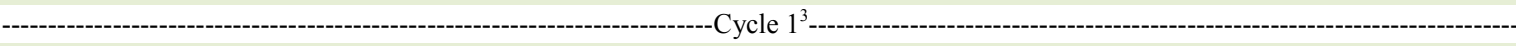 } \\
\hline & Number of plants obtained & Number of plants evaluated & Number of $4 x$ plants \\
\hline $0.1 \%$ colchicine $+1 \%$ DMSO & 81 & 53 & 14 \\
\hline $0.25 \%$ colchicine $+1 \%$ DMSO & 83 & 43 & 19 \\
\hline Total & 164 & 96 & 33 \\
\hline \multicolumn{4}{|c|}{ - } \\
\hline & Number of plants obtained & Number of plants evaluated & Number of $4 x$ plants \\
\hline $0.1 \%$ colchicine $+1 \%$ DMSO & 66 & 66 & 61 \\
\hline $0.25 \%$ colchicine $+1 \%$ DMSO & 52 & 52 & 47 \\
\hline Total & 118 & 118 & 108 \\
\hline
\end{tabular}

${ }^{1}$ Number of plants surviving plants.

${ }^{2}$ Number of $4 \mathrm{x}$ plants - Plants identified and evaluated in flow cytometry as tetraploid (4X).

${ }^{3}$ Plants obtained from seeds of the tetraploid plants of the cycle 0 .

${ }^{4}$ Plants obtained from seeds of the tetraploid plants of the cycle 1.

mixoploid plants reoccurred after one generation. Cycle 1 exceded by $16 \%$ the number of tetraploid plants in relation to the initial cycle (Cycle 0).

Seeds of the 33 tetraploid plants obtained in cycle 1 produced 118 plants in cycle 2 , among which, $92 \%$ were identified as tetraploid by flow cytometry (Table 1). These data showed an increase of $74 \%$ and $58 \%$ in relation to cycles 0 and 1 , respectively. This was largely due to the selection strategy used in this generation, consisting of eliminating all the progeny, even though only a few plants were not tetraploid, according to DNA quantification. After two generations of selection, about $92 \%$ of tetraploid plants were observed.

The chromosome number of all plants identified as tetraploids in cycle 0 validated the information obtained by flow cytometry. However, chromosome counts of the plants in the cycles 1 and 2, previously characterized as tetraploid by flow cytometry, suggested the occurrence of mixoploidy, because the progenies showed chromosome number ranging from 14 to 28 chromosomes in cells of the same root.

Plants identified as tetraploids by DNA quantification and even those confirmed later as mixoploid, through chromosome counting, were isolated and showed viable seed production.

Results demonstrated that polyploidy induction requires time and careful screening and selection until the plants acquire stability in chromosome number. This indicated the need for monitoring polyploids over generations, in order to ensure greater safety before commercial use and incorporation into breeding programs. In addition, this monitoring is important to check for reversion to the original diploid condition, as well to detect mixoploidy and related problems to fertility and agronomic behavior of the individuals. This corroborated the results obtained by NAIR (2004) in artificially tetraploidized $L$. perenne plants. This author has evaluated two generations of synthetic polyploids of this species originating from the treatment of seedlings with colchicine. In the first and second generations, $25 \%$ and $43 \%$ of plants were tetraploids, respectively. Therefore, there was a 18 percent points increase in the percentage of polyploids in the subsequent generation. In this study, we recovered more tetraploid plants than NAIR (2004), respectively, $34 \%$ and $92 \%$ of tetraploid individuals in the first and second generations. 
In B. ruziziensis, Timbó et al. (2014) obtained eight polyploid plants from a total of 1,200 seedlings treated with $0.1 \%$ colchicine $/ 2 \mathrm{~h}$ and $3 \mathrm{~h}$, which produced viable pollen. These plants were incorporated into the B. ruziziensis breeding program conducted by Embrapa Gado de Leite, Juiz de Fora, Minas Gerais State, and were intercrossed and produced progenies with pollen viability higher than 90\% (PAULA et al., 2014). In this study with Brachiaria, the authors observed that the fertility of tetraploid progenies, analyzed by pollen viability, was higher than the initial generation, indicating a possible higher stability over generations.

Results obtained in two generations of L. multiflorum showed a tendency for the maintenance of stability in terms of DNA content and viable seed production for plants recently poliploidized by PEREIRA et al. (2014). Besides that, the production of viable seeds in mixoploid plants may be an indication that the variation in chromosome number does not impair plant fertility; and therefore, does not prevent the use of these plants in breeding.

One of the factors that may contribute to the occurrence of mixoploid plants is the time of exposure to antimitotic substances. In Pennisetum, ABREU et al. (2006) observed that prolonged exposure to antimitotic drugs generated a greater number of cells with changes in the chromosome number.

Except for the cycle 0, chromosome counts have not confirmed the results obtained by flow cytometry, in both effectively tetraploidized and mixoploid plants, evidencing that the cytogenetic analysis is still the most reliable technique to access the results of polyploidization processes.

In this sense, after polyploidization process, it is necessary to monitor the synthetic polyploids for subsequent generations to verify the chromosomal and phenotypic stability and the possible delayed effects of colchicine (LUCKETT, 1989; CASTRO et al., 2003). In addition, such analysis can show if the variation in chromosome number impairs fertility and stability of plants in the field, which is undesirable from a commercial point of view and for breeding purposes.

\section{CONCLUSION}

The results showed that stabilization in chromosome number and DNA content in tetraploidized plant progenies requires at least two generations and that the success of this procedure depends on a continuous and accurate screening and selection.

\section{ACKNOWLEDGEMENTS}

The authors thank to the Conselho Nacional de Desenvolvimento Científico e Tecnológico (CNPq), Fundação de Amparo a Pesquisa no Estado de Minas Gerais (FAPEMIG), Coordenação de Aperfeiçoamento de Pessoal de Nível Superior (CAPES) for the financial support and to FAPEG/ SULPASTO for the scholarship for the second author.

\section{REFERENCES}

ABREU, J.C. de. et al. Mixoploidia em híbridos de capim-elefante x milheto tratados com agentes antimitóticos. Pesquisa Agropecuária Brasileira, v.41, n.11, p.1629-1635, 2006. Available from: <http:// www.scielo.br/pdf/pab/v41n11/a09v4111.pdf >. Accessed: May 27, 2015. doi: 10.1590/S0100-204X2006001100009.

BARBOSA, S. et al. Chromosome duplication of triploid hybrids between elephantgrass and pearl millet. Bragantia, v.66, n.3, p.365-372, 2007. Available from: <http://dx.doi.org/10.1590/ S0006-87052007000300001>. Accessed: May 25,2015. doi: 10.1590/S0006-87052007000300001.

CAMPOS, J.M.S. et al. In vitro induction of hexaploid plants from triploid hybrids of Pennisetum purpureum and Pennisetum glaucum. Plant Breeding, v.128, n.1, p.101104, 2009. Available from: <http://onlinelibrary.wiley.com/ doi/10.1111/j.1439-0523.2008.01546.x/full>. Accessed: May 25, 2015. doi: 10.1111/j.1439-0523.2008.01546.x.

CASTRO, C.M. et al. Changes in allele frequencies in colchicinetreated ryegrass populations assessed with RAPD markers. Revista Brasileira de Agrociência, v.9, p.107-112, 2003. Available from: $<$ http://www2.ufpel.edu.br/faem/agrociencia/v9n2/artigo02.htm>. Accessed: May 25, 2015. doi: 10.18539/CAST.V9I2.523.

DOLEZEL, J. Application of flow cytometry for the study of plants genomes. Journal of Applied Genetics, v.38, n.3, p.285-302, 1997. Available from: <http://agris.fao.org/agris-search/search. do?recordID=PL1998000505>. Accessed: May 25, 2015.

ISHIGAKI, G. et al. Induction of tetraploid ruzigrass (Brachiaria ruziziensis) plants by colchicine treatment of in vitro multipleshoot clumps and seedlings. Grassland Science, v.55, n.3, p.164-170, 2009. Available from: <http://onlinelibrary.wiley.com/ doi/10.1111/j.1744-697X.2009.00153.x/pdf.>. Accessed: May 27, 2015. doi: 10.1111/j.1744-697X.2009.00153.x.

LUCKETT, D. Colchicine mutagenesis is associated with substantial heritable variation in cotton. Euphytica, v.42, n.12, p.177-182, 1989. Available from: <http://www.springerlink. com/content/j226078w0653571n/>. Accessed: May 27, 2015. doi:10.1007/BF00042630.

NAIR, R.M. Developing tetraploid perennial ryegrass (Lolium perenne L.) populations. New Zealand Journal of Agricultural Research, v.47, n.1, p.45-49, 2004. Available from: <http://www.tandfonline.com/doi/abs/10.1080/002 88233.2004.9513569\#preview>. Accessed: May 25, 2015. doi: 10.1080/00288233.2004.9513569. 
PAULA, C.M.P. et al. Intra-inflorescence pollen viability in accessions of Brachiaria ruziziensis. Acta Scientiarum Biological Science, v.36, n.2, p.209-213, 2014. Available from: <http://periodicos.uem. br/ojs/index.php/ActaSciBiolSci/article/view/19440>. Accessed: May 25, 2015. doi: 10.4025/actascibiolsci.v36i2.19440.

PEREIRA, A.V. et al. Melhoramento de forrageiras tropicais. In: NASS, L.L. et al. Recursos genéticos e melhoramento de plantas Rondonópolis: Fundação Mato Grosso, 2001. Cap.18, p.549-602.

PEREIRA, R.C. et al. Chromosome duplication in Lolium multiflorum Lam. Crop Breeding and Applied Biotechnology, v.14, n.3, p.251-255, 2014. Available from: $<$ http://dx.doi. org/10.1590/1984-70332014v14n4n39>. Accessed: May, 27, 2015

PINHEIRO, A. A. et al. Duplication of the chromosome number of diploid Brachiaria brizantha plants using colchicine. Plant Cell
Reports, v.19, n.3, p.274-278, 2000. Available from: <http://www. cabdirect.org/abstracts/20001608929.html.>. Accessed: May 26, 2015. doi: 10.1007/s002990050011.

SIMIONI, C.; VALLE, C.B. Chromosome duplication in Brachiaria (A. Rich.) Stapf allows intraspecific crosses. Crop Breeding and Applied Biotechnology, v.9, n.4, p.328-333, 2009. Available from: <http://www.scielo.br/ scielo.php?pid $=\mathrm{S} 1984-70332011000100006 \&$ script $=$ sci arttext>. Accessed: May 26, 2015. doi: 10.1590/S198470332011000100006 .

TIMBÓ, A.L.O. et al. Obtaining tetraploid plants of ruzigrass (Brachiaria ruziziensis). Revista Brasileira de Zootecnia, v.43, p.127-131, 2014. Available from: <http://dx.doi.org/10.1590/S151635982014000300004>. Accessed: May 27, 2015. doi:10.1590/ S1516-35982014000300004. 